\title{
De duur van de competentiegerichte medisch specia- listische vervolgopleiding kan niet korter
}

\author{
A. Horsch, S. van den Tillaart, S. Tulner
}

\section{Inleiding}

Van oudsher bedraagt de duur van de opleiding tot medisch specialist in Nederland, afhankelijk van de gekozen richting, vier tot zes jaar. Er gaan stemmen op om deze in te korten. Dit is om meerdere redenen een slechte zaak.

Om het hoge niveau van ervaring en routine te verkrijgen dat van de huidige medisch specialist verwacht mag worden, moeten er tijdens de vervolgopleiding zowel voldoende patiëntencontacten zijn geweest als procedures zijn uitgevoerd. De exponentiële toename van de medische kennis en de in de huidige tijd noodzakelijke, bijkomende vaardigheden, samengevat in de CanMEDS competenties, vragen veel extra inzet en tijd van de toekomstig medisch specialist om zich deze eigen te maken. Ondanks de lange werkweken en de zelfstudie daarnaast is het noodzakelijk de huidige opleidingsduur te handhaven. In de praktijk is het bereikbaar houden van deze doelen al begonnen met de komst van de differentiaties in het kader van de modernisering van de medische vervolgopleidingen. Ook zijn er fellowships ingevoerd die het opleidingstraject met één tot twee jaar verlengen.

\section{Ontwikkelingen in de vervolgopleiding} Sinds geruime tijd bestaan er voor artsen in opleiding tot specialist (aios) goede regelingen voor zwangerschapsverlof, ouderschapsverlof en deeltijdwerk. Ook zijn de in het verleden onredelijk lange werkweken aan banden gelegd door de invoering van het werktijdenbesluit. Dit is een groot goed, waarvoor de Jonge Orde zich in het verleden heeft hard gemaakt. Een bijkomend effect van deze regelingen is echter de fragmentatie van de werktijden en daarmee van de leermomenten. Omdat de meeste vaardigheden van de aankomende specialisten 'hands-on' geleerd moeten worden,en veel herhaling de effectiefste methode is, moeten voldoende leermomenten gewaarborgd zijn. In de huidige opleidingsduur en -opzet is dit haalbaar zij het met een grote inzet en veel organisatietalent van zowel de aios als de supervisor. Het verkorten van de opleiding zal leiden tot minder leermomenten.

Een ander kritisch punt dat hierbij ook genoemd moet worden is het gegeven dat de aios momenteel veel tijd kwijt zijn aan het verrichten van louter administratieve arbeid. Deze inspanning doet geen recht aan de capaciteiten en aan het vak waarvoor de aios worden opgeleid.

Ook kunnen aios sommige taken van medisch specialisten overnemen of hierbij ondersteunend zijn. Een deel van de productie wordt door de aios tussen 8.00 uur 's ochtends en 17.00 uur 's middags uitgevoerd, maar dat niet alleen: tijdens de diensten 's avonds, 's nachts en in de weekenden fungeren ze als belangrijkste aanspreekpunt. De aios leren weliswaar veel tijdens dergelijke werkzaamheden, maar zijn ermee vaak ook onvervangbaar voor het ziekenhuis. Bij verkorting van de opleiding zal ook op deze werkzaamheden gekort worden. De leermomenten vinden immers verspreid over de dag en de nacht plaats. Als deze werkzaamheden door medisch specialisten zelf gedaan zouden 
moeten worden, zal dit leiden tot grote personele tekorten en inherent hieraan tot verlenging van de wachtlijsten en -tijden en kostenstijgingen. Gezien de recente ontwikkelingen om de kosten van de gezondheidszorg binnen het macrobudgettair kader van MEVA te houden is dit een belangrijk gegeven.

\section{Conclusie}

Samenvattend kan gesteld worden dat

- voldoende patiëntencontacten en voldoende ervaring in het verrichten van procedures noodzakelijk zijn. Hierin voorziet de huidige opleidingsduur,

- gezien de toenemende medische kennis en technologische vooruitgang er steeds meer geleerd moet worden,

- door regelingen ten behoeve van een betere werk-/privebalans fragmentatie van leermomenten optreedt,
- het macrobudgettair aantrekkelijk is om aios de benodigde leermomenten gedurende dag en nacht te laten houden.

Kortom, alles pleit ervoor niet tot verkorting van de opleidingduur over te gaan.

De auteurs:

Drs. Alexander Horsch is ... *

Drs. Sabrina van den Tillaart is ... *

Drs. Sven Tulner is... *

* Allen zijn lid van het bestuur van de Jonge Orde

Correspondentieadres:

.........

Belangenconflict: geen gemeld

Financiële ondersteuning: geen gemeld 